Apidologie, 1978, 9 (1), 75-89.

\title{
CHALKBROOD DISEASE OF HONEY BEES, APIS MELLIFERA L. : A PROGRESS REPORT
}

\author{
Martha GILLIAM, Stephen TABER III, Joan BRAY ROSE. \\ Agricultural Research Service, U.S. Department of Agriculture, Bee Research Laboratory, \\ 2000 East Allen Road - Tucson, Arizona 85719
}

\section{SUMMARY}

Under a variety of conditions affecting both the pathogen and the host colonies, many attempts were made to infect brood in apiary colonies with Ascosphaera apis. However, variation in susceptibility of bee colonies appeared to be an important factor in the expression of chalkbrood disease.

Thus, we devised techniques for harvesting, sterilizing, maintaining, and inoculating large numbers of eggs, larvae, and pupae in an incubator. Mummies were produced from larvae and prepupae, but eggs and pupae did not support the growth of A. apis. Infection occured both through ingestion of A. apis and by the growth of the fungus through the cuticle. Ascosphaera apis grew on dead larvae killed with dry ice but did not mummify them.

\section{I. - INTRODUCTION}

Chalkbrood disease of honey bees, Apis mellifera L., is thought to be caused by the heterothallic fungus, Ascosphaera apis (Maassen ex Claussen) OLIve and SPILTOIR. Spores are formed within fruiting bodies only when mycelia of opposite sex come together. Diseased larvae become mummified. The mummies are white due to the mycelium of the fungus. However, if fruiting bodies are formed, the mummies are dark gray or black.

Unfortunately, little is known of the epidemiology and pathogenesis of chalkbrood disease. According to BAILEY (1967), honey bee larvae are most susceptible to chalkbrood disease if they ingest spores of $A$. apis when they are 3-4 days old and are then chilled 2 days later after they are sealed in their cells to pupate. The spores then germinate in the gut of the larvae. Initially the dead larvae are covered with a white fluffy 
growth of mycelia and are swollen to the size of the cell. Later they dry into a hard, shrunken chalk-like lump that may become gray to black if fruiting bodies are formed. The remains of larvae can be found in sealed or unsealed cells.

Barthel (1971) and MATUS and SARBaK (1974) stated that natural infection by $A$. apis could occur either by ingestion of spores with food or via the body surface from spores on combs and cell walls. Roussy (1962) found that the spores germinated on the surface of larvae, whereas MAURIzio (1934) thought that infection was through the mouth and not through the cuticle or spiracles.

Chalkbrood disease has been reported from Europe for many years. However, it was not reported from the United States until BAKER and Torchio (1968) found $A$. apis associated with a leaf cutter bee, Megachile inermis Provancher and a soil nesting bee, Anthophora pacifica Cresson. Later ThOMAs and LUCE (1972) reported chalkbrood from honey bees in California, and HrTCHCOCK and CHRistensEN (1972) found the disease in honey bee larvae from Nebraska and Wyoming. We first found the disease in bees from Arizona in May, 1972 (Gilliam and TABER, 1973). The disease now appears to be widespread in bees in the United States.

DE JONG and MORSE (1976) noted the difficulty that researchers have experienced in inducing chalkbrood infections in bees for study. Since 1972, we have been conducting experiments on the transmission of $A$. apis. Specifically, we have been attempting to infect brood artificially. Such infections would give information on the transmission and pathogenesis of the disease and would provide a reproducible bioassay. They would also allow us to perform controlled experiments on methods of treatment such as the use of mold inhibitors (TABER et al., 1975). In this paper, we report the work that we have conducted on full-size colonies in the apiary and on brood maintained in an incubator.

\section{II. - ATTEMPTS TO INFECT APIARY COLONIES WITH $A$. $A P I S$}

\section{1. - Use of A. apis cultures}

Cultures were prepared by placing a mummy or several mummies of the same color in a test tube containing $15 \mathrm{ml}$ of Sabouraud dextrose broth with $0.2 \%$ yeast extract (SDB-YE) (Thomas and LuCE, 1972). The tubes were incubated at $25^{\circ} \mathrm{C}$ until good growth occured (usually 1-2 weeks). The contents of each tube were then placed in a separate flask containing $250 \mathrm{ml}$ of SDB-YE. The flasks were incubated on an orbital shaker for 1-2 weeks. For some experiments, the contents of the flasks were centrifuged. The centrifuged material was washed once or twice in sterile distilled water, centrifuged again, and suspended in sterile distilled water. Other centrifuged material was not washed but immediately resuspended in sterile distilled water. When centrifuged material was used to treat bees, centrifugation took place immediately before use. In some cases, uncentrifuged SDB-YE cultures were used to treat bees. 
Before treatment, bee colonies were fed untreated pollen cakes (TABER and PoOLE, 1974) until they contained large numbers of larvae of all ages. Then various concentrations of the culture materials from white or black mummies were used to treat bee colonies. After the culture materials were sprayed on the brood and the adult bees around the brood, the remainder of the fungal material was mixed in a pollen cake and fed to the colony. Some colonies were not sprayed but were fed pollen cakes containing the fungus. Viability of the fungus in the pollen cakes and sprays was confirmed by plating the materials on SDA-YE plates.

In all these attempts, only a few mummies with chalkbrood disease were found within 10 days in each treated colony. Ten days after treatment, no more mummies were found. However, discolored larvae were removed from the colonies, placed in separate sterile vials, and incubated at $25^{\circ} \mathrm{C}$ for several weeks. [In this work, as well as in all the other experiments reported in this paper, we found no differences as reported by Roussy (1962) when cotton stoppers soaked in distilled water or screw caps were used with the vials.] The larvae infected with $A$. apis mummified in the incubator within 1-4 days. Plating confirmed infection by $A$. apis.

\section{2. - Use of mummies in $5 \%$ sucrose}

Next, by holding a mummy with forceps, we shook the material from one mummy into $5 \mathrm{ml}$ of $5 \%$ sucrose syrup. This procedure was repeated with 4 additional mummies of the same color for a total volume of $25 \mathrm{ml}$ per treatment. This material was sprayed on the brood and the bees around the brood in several colonies and was also fed to bee colonies. Other colonies were fed the material every other day for a total of 3 feedings.

Then a spray was prepared by gently homogenizing a mummy in a glass tissue grinder containing $30 \mathrm{ml}$ of $5 \%$ sucrose syrup. The mummy was removed, and the solution was sprayed on the brood and the bees around the brood. Each colony so treated was sprayed 3 times at 48 -hour intervals. Some colonies were sprayed with material from white mummies, others with material from black mummies, and still others with black and white mummy material alternated.

In addition, we removed $0,0.45$, or $1.2 \mathrm{~kg}$ of worker bees from colonies to alter the ratio of adult bees to brood (DE JONG, 1976) and then sprayed the colonies with the A. apis suspensions every other day for a total of 3 sprays. Other colonies were sprayed 3 times a day on alternating days. Alteration of the ratio was accomplished in other colonies by removal of frames of brood or by selecting colonies for spray or feeding treatment that contained 5 frames or 10 frames of brood. Dead bee traps (ATKINS et al., 1970) were placed on the colonies to collect mummies. Mummies were collected from the traps, the bottoms of the hives, the entrances, and cells. We noted that larvae with early stages of $A$. apis infection were removed from their cells by adult bees within 16 hours. 
In other trials, colonies were fed untreated pollen cake for 2 weeks before they were sprayed and thereafter for the duration of the experiment to ensure that large numbers of larvae were present. Then varying amounts of adult bees were removed from the hives. Some of these colonies were sprayed 3 times a day on alternate days with $90 \mathrm{ml}$ of $5 \%$ sucrose syrup containing the homogenate of 3 mummies of the same color. In these latter colonies with large numbers of larvae that were sprayed 3 times daily with material from black mummies, we obtained the heaviest infections 6 days after the initial treatment; approximately $10 \%$ of the brood was mummified, and the mummies were black. However, attempts to reproduce these high levels of infection at other times in other colonies by using the same techniques were unsuccessful. Thus, some colonies may be more susceptible to infection, or they may have bees that do not clean the hive well.

\section{3. - Use of mummies in talc and pollen cakes}

Next we placed 1-3 mummies in a $30 \mathrm{ml}$ volume of talc, ground the mummies with a mortar and pestle, and dusted the material onto brood combs of colonies. Few larvae with chalkbrood were found in any of these colonies.

Mummies were also incorporated into pollen patties and fed to cclonies. No disease was found in these colonies.

\section{III. - ATTEMPTS TO INFECT BROOD IN AN INCUBATOR WITH $A$. $A P I S$}

$$
\text { 1. - Effects of royal jelly on A. apis }
$$

Because of the difficulty of inducing infections in apiary colonies, we began work to develop methods for infecting brood maintained in an incubator. Initially we planned to feed $A$. apis in royal jelly to the larvae. To ascertain whether the antibiotic properties of royal jelly might inhibit $A$. apis, we made tests of the sensitivity of cultures of $A$. apis to royal jelly. Plates of SDA-YE were heavily overlayed with royal jelly over either the entire surface or over half the surface. Then some plates were streaked with mated strains of $A$. apis and others with unmated strains. Control plates of SDA-YE medium were streaked with $A$. apis strains or royal jelly. All plates streaked with $A$. apis showed prolific growth of the organism. The plates streaked with royal jelly only showed no growth.

Also, A. apis was mixed with royal jelly and incubated for 24 hours. The mixture was then streaked on SDA-YE plates. Good growth of $A$. apis was obtained on all plates. Thus, from these preliminary experiments, royal jelly did not appear to have any inhibitory effect on the viability or growth of $A$. apis and hence would not be expected to affect subsequent studies on laboratory-reared larvae. 


\section{2. - Attempts to infect 3-4 days old larvae with A. apis}

We sought to determine whether $A$. apis causes chalkbrood disease or is simply a secondary invader of larvae killed or injured by other events. Evidence for the latter might be supported by mummification of on dead larvae. We also wished to determine whether mummification arises from infection by both vegetative and sporulated strains and whether $A$. apis can invade larvae through the cuticle and/or per os.

Larvae, 3-4 days old, were removed from their cells with forceps. Then sterile forceps were used to pass each larva individually through 3 separate washes of sterile distilled water to remove external debris and microorganisms. Table 1 gives the treatment groups of larvae.

TABL. 1. - Treatment groups of 3-4 day old larvae inoculated with Ascosphaera apis ${ }^{a}$.

\begin{tabular}{|l|l|l|}
\hline \multicolumn{2}{|c|}{ Site of inoculation } & \\
\hline \multicolumn{1}{|c|}{ " Alive " Larvae } & \multicolumn{1}{|c|}{ "Dead " Larvae } & A. apis strain \\
\hline Mouthparts & Mouthparts & Mated-live \\
Mouthparts & Mouthparts & Unmated-live \\
Back & Back & Mated-live \\
Back & Bask \\
Mouthparts & Mouthparts & Mated-dead \\
Mouthparts & Mouthparts & Unmated-dead \\
Back & Back & Mated-dead \\
Back & Back & Unmated-dead \\
\hline a lo larvae per treatment group. & \\
\hline
\end{tabular}

Larvae in the " alive " treatment groups were individually placed in sterile vial caps in sterile glass petri dishes that contained a piece of filter paper kept moist with sterile distilled water. Eight-10 larvae receiving the same treatment were placed in the same petri dish. Larvae in the "dead" treatment groups were placed in sterile vial caps and petri dishes and were frozen for $30-45 \mathrm{mn}$ at $-70^{\circ} \mathrm{C}$.

Ascosphaera apis suspensions for inoculation of the larvae were prepared by grinding 5 black mummies (mated strain) or 5 white mummies (unmated strain) in $5 \mathrm{ml}$ of sterile distilled water in a glass tissue grinder. These suspensions were plated to confirm viability and were also sprayed on combs in apiary colonies. Some mummies were found in sprayed combs after 5 days. The dead A. apis suspensions used for controls were obtained by autoclaving the homogenate.

A drop of the appropriate homogenate was placed either on the mouthparts or on the dorsal side of the larvae. We confirmed consumption of the homogenate by direct 
observation. The dishes were placed in a $25^{\circ} \mathrm{C}$ incubator. Larvae were observed daily for 8 days with a dissecting microscope for movement, fungal growth, discoloration, and mummification.

No characteristic mummies were produced, but 21 of 40 live larvae treated with viable A.apis showed evidence of infection. They were approximately equally distributed between those inoculated on the mouthparts and on the back, probably because the larvae crawl in the vial caps. However, twice as many (14) of the larvae showing growth of A.apis were inoculated with mated A.apis as with unmated strains. A. apis was found on the cuticle and in the body fluids.

No growth of $A$. apis or any other microorganism was found on larvae inoculated with autoclaved $A$. apis. Larvae killed by freezing supported little microbial growth.

We concluded that our method of collection of larvae was too harsh and too timeconsuming since some larvae that were apparently injured during collection or washing showed no signs of injury such as bleeding or cessation of movement until several days after the start of the experiment. At that time, bleeding was evident, and the larvae became flat. However, aseptic methodology was adequate since only 3 of 160 larvae treated were contaminated with exogenous microorganisms.

\section{3. - Development of methods for utilizing larvae for infectivity tests}

Damage to larvae was subsequently reduced by employing the water removal technique of GARY et al. (1961) without removing any cappings from the cells. The larvae were washed onto sterile absorbent paper and rinsed with sterile distilled water. They were then transferred to a fresh sheet of sterile paper and rinsed again with sterile distilled water. This procedure was repeated once more for a total of 3 rinses.

The larvae were divided into two age groups, small and large, on the basis of size. The small larvae were 3-4 days old (average weight $54 \mathrm{mg}$ ), and the large larvae were 4.5-5.5 days old (average weight $134 \mathrm{mg}$ ).

Individual larvae were transferred with sterile forceps to sterile vial caps. Seven10 larvae of the same age group were placed in a sterile petri dish lined with sterile filter paper kept moist with sterile distilled water.

Table 2 shows the treatment groups of larvae. Larvae in the "alive " treatment groups were fed nothing, a drop of $25 \%$ sucrose solution on the mouthparts, or a drop of royal jelly that was placed in the center of the curled larva. They were fed daily. Larvae in the "dead" treatment groups were killed with either a drop of acetone or a piece of dry ice.

All petri dishes containing larvae were incubated at $25^{\circ} \mathrm{C}$ for 5 days. The larvae were observed daily for movement, darkening, bleeding, loss of integrity, and microbial contamination. 
The water removal technique provided 170 larvae in a short time with microbial contamination in only 9 individuals. However, too many larvae were still injured in the forceps transfer from the paper to the vial caps.

TABL. 2. - Treatment groups of small and large larvae from uncapped cells utilized to improve methods of collection and maintenance of larvae.

\begin{tabular}{|l|l|l|l|c|}
\hline \multicolumn{1}{|c|}{ Larvae } & \multicolumn{1}{|c|}{ Size } & \multicolumn{1}{c|}{ Treatment } & \multicolumn{1}{c|}{ Diet } & Number \\
\hline Alive & Small & None & None & 20 \\
Alive & Small & None & 25\% Sucrose & 20 \\
Alive & Small & None & Royal jelly & 5 \\
Alive & Large & None & None & 20 \\
Alive & Large & None & 25\% Sucrose & 20 \\
Alive & Large & None & Royal jelly & 5 \\
Dead & Small & Dry ice & None & 20 \\
Dead & Small & Acetone & None & 20 \\
Dead & Large & Dry ice & None & 20 \\
Dead & Large & Acetone & None & 20 \\
\hline
\end{tabular}

A drop of acetone was not effective in killing all larvae. The dry ice method was superior, and most of the larvae maintained their integrity.

Larvae fed royal jelly became swollen, and a few of them were glued to the bottom of the cap with dried royal jelly. Otherwise, there were no differences in larval survival between the groups fed sucrose solution, royal jelly, or nothing.

\section{4. -Attempts to infect small and large larvae from uncapped cells with $\mathrm{A}$. apis}

The objectives of this experiment were the same as those in Test 2. In addition, we wished to determine whether young and old larvae are equally susceptible to infection.

Therefore, further trials were made with larvae divided into age groups on the basis of size : small (3-4 days old) and large (4.5-5.5 days old). After being washed from the comb, each larvae was individually picked up on the polished end of a glass tube attached to a water suction device. While held to the glass tube, each was washed 3 times with sterile distilled water from a plastic squeeze bottle. Each larva was placed in a vial cap, and the vial caps were placed in petri dishes as before.

The treatment groups of larvae are shown in Table 3. Larvae in the " dead " treatment groups were killed with dry ice. The inoculum in this series was prepared by homogenizing 5 black spore-bearing mummies or 5 white chalky mummies in $5 \mathrm{ml}$ of 
sterile distilled water in a sterile glass tissue grinder. The suspensions of " dead A. apis " were autoclaved. All preparations were kept in sterile glass vials.

TABL. 3. - Treatment groups of small and large larvae from uncapped cells used to determine the pathogenic and saprophytic properties of Ascosphaera apis.

\begin{tabular}{|c|c|c|}
\hline Treatment & $\begin{array}{l}A, \text { apis } \\
\text { strain }\end{array}$ & $\begin{array}{l}\text { Site of } \\
\text { inoculation }\end{array}$ \\
\hline 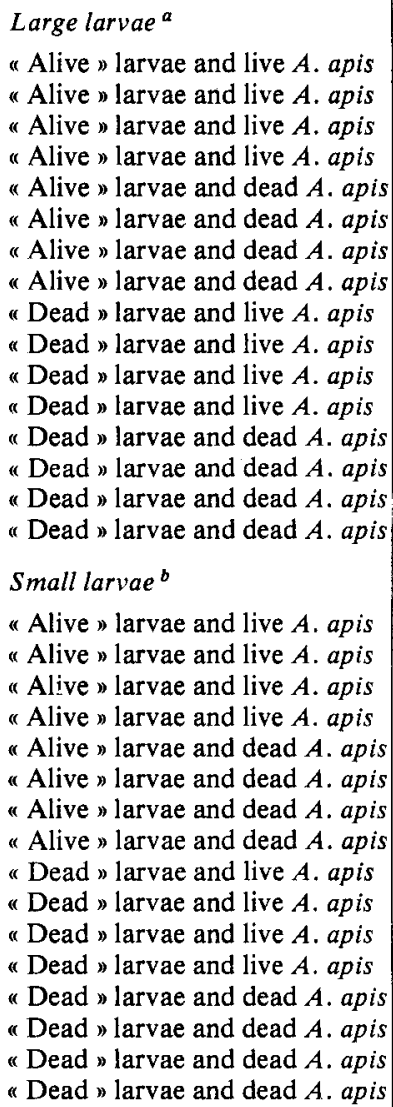 & $\begin{array}{l}\text { Mated } \\
\text { Unmated } \\
\text { Mated } \\
\text { Unmated } \\
\text { Mated } \\
\text { Unmated } \\
\text { Mated } \\
\text { Unmated } \\
\text { Mated } \\
\text { Unmated } \\
\text { Mated } \\
\text { Unmated } \\
\text { Mated } \\
\text { Unmated } \\
\text { Mated } \\
\text { Unmated }\end{array}$ & $\begin{array}{l}\text { Mouthparts } \\
\text { Mouthparts } \\
\text { Back } \\
\text { Back } \\
\text { Mouthparts } \\
\text { Mouthparts } \\
\text { Back } \\
\text { Back } \\
\text { Mouthparts } \\
\text { Mouthparts } \\
\text { Back } \\
\text { Back } \\
\text { Mouthparts } \\
\text { Mouthparts } \\
\text { Back } \\
\text { Back }\end{array}$ \\
\hline $\begin{array}{l}\text { a } 20 \text { larvae per test. } \\
\text { b } 10 \text { larvae per test. }\end{array}$ & & \\
\hline
\end{tabular}

Microbial contamination of larvae was a problem in this test. All the contaminants were molds, primarily Penicillium spp. and Aspergillus spp., which were probably comb inhabitants washed onto the larvae. 
The results are shown in Table 4. Eleven mummies were formed in control treatment groups receiving dead $A$. apis; these larvae may have had natural infections that were inapparent until the larvae were incubated. However, none of the colonies from which larvae were obtained contained any larvae that were visibly infected with A. apis. Nor were any mummies found at the entrance or on the bottoms of these colonies. Therefore, some bee colonies or larvae may harbor A. apis without showing signs of disease. Small larvae that were naturally infected required 5-7 days of incubation to mummify; large larvae required 6-8 days.

TABL. 4. - Larvae experimentally infected with Ascosphaera apis.

\begin{tabular}{|c|c|c|c|c|c|c|}
\hline \multirow{2}{*}{ Larvae } & \multirow{2}{*}{$\begin{array}{c}\text { Site of } \\
\text { inoculation }\end{array}$} & \multirow{2}{*}{$\begin{array}{l}\text { A. apis } \\
\text { strain }\end{array}$} & \multicolumn{2}{|c|}{ Mummies produced } & \multicolumn{2}{|c|}{ Larvae with $A$. apis growth } \\
\hline & & & Black & White & Mycelium & Spores \\
\hline Small-alive & Mouthparts & Live-mated & 1 & 2 & & \\
\hline Small-alive & Mouthparts & Live-unmated & 5 & & & 5 \\
\hline Small-alive & Back & Live-mated & 1 & & & \\
\hline Small-alive & Back & Live-unmated & 3 & & 1 & 2 \\
\hline Small-alive & Mouthparts & Dead-mated & 2 & & & \\
\hline Small-alive & Back & Dead-mated & 2 & 1 & & \\
\hline Small-dead & Back & Live-unmated & & & 5 & \\
\hline Large-alive & Mouthparts & Live-mated & 7 & 2 & 2 & 1 \\
\hline Large-alive & Mouthparts & Live-unmated & 6 & 3 & 4 & \\
\hline Large-alive & Back & Live-mated & 2 & 7 & & \\
\hline Large-alive & Back & Live-unmated & 4 & & 2 & \\
\hline Large-alive & Mouthparts & Dead-unmated & & 3 & & \\
\hline Large-alive & Back & Dead-mated & & 3 & & \\
\hline Large-dead & Mouthparts & Live-unmated & & & 1 & 14 \\
\hline Large-dead & Back & Live-unmated & & & 6 & 7 \\
\hline
\end{tabular}

No mummies were formed as a result of the inoculation of dead larvae with A. apis. However, A. apis did grow on 33 of these larvae. Thus, it appears that $A$. apis can grow and in some instances sporulate on dead larvae but will not mummify them.

Forty-three mummies were formed as a result of inoculation of larvae with live $A$. apis. Both the small and large larvae required 5-7 days after inoculation for mummy formation. Twenty-six of the mummies were produced by inoculation of mouthparts and 17 by inoculation on the back. Thus, infection may occur per os and through the cuticle. We observed the fungus growing from the mouth, the anus, and through the cuticle of larvae inoculated on the mouthparts. The fungus appeared to grow first aerially at the point of inoculation on larvae inoculated on the back. It then grew throughout the entire body, and the larvae became mummified. All experimentally produced mummies were much flatter than those generally found in bee colonies.

Both mated and unmated strains of A. apis caused mummy formation. Of the mummies produced from the material prepared from black mummies, 11 were black and 11 were white. However, of the mummies produced by inoculation of material prepared from white mummies, 18 were black and only 3 were white. Thus, by selec- 
ting 5 mummies for production of the inoculum, we obviously mixed + and - strains to produce the mated strains that infected the larvae. However, it is interesting that an equal number of black and white mummies were formed from material prepared from black mummies. A separation of $+/-$ material could have occurred or, perhaps, sporulation was in some way inhibited.

Small and large larvae were equally susceptible to infection since we used twice as many large larvae as small ones. Thirty-one mummies were produced among large larvae and 12 among small larvae. Thus, 3-4 day old and 4.5-5.5 day old larvae appear to be susceptible to chalkbrood disease. This conjecture is reinforced by the fact that 5 of the small and 6 of the large larvae apparently had a natural infection of chalkbrood.

\section{5. - Sterilization of larvae with a germicide}

Since contamination of larvae with molds was a problem in the previous experiment, we conducted this test to develop a method of surface sterilization of larvae with a germicide. We wished to eliminate the contaminants without harming the larvae.

After the larvae were washed from a comb onto a sterile Masslinn $R$ towel, they were given one of 3 treatments. Thirty-five larvae were individually picked up with the suction apparatus, washed with a $1: 1,250$ solution of Roccal ${ }^{R}$ from a plastic squeeze bottle, and rinsed twice with sterile distilled water from a squeeze bottle. They were placed on sterile paper to blot them dry and were then put into sterile vial caps in petri dishes by releasing the suction. Fifteen other larvae were given the same treatment without the distilled water washings. Thirty-five larvae were left on the towel and rinsed with Roccal. Then they were picked up by suction, rinsed twice with sterile distilled water, and placed in vial caps. All petri dishes contained a piece of filter paper kept moist with sterile distilled water.

All larvae were incubated at $25^{\circ} \mathrm{C}$ and observed daily for 5 days for microbial contamination, injury, and death.

All procedures were effective in eliminating microbial contamination. Only 4 of the 84 larvae showed any microbial growth, and they were equally distributed among the 3 treatment groups. Larvae not rinsed with water after washing with Roccal had a higher incidence of death than those that were rinsed. Larvae that were picked up by suction and then rinsed with Roccal and water had the fewest deaths. Therefore, we decided to follow this procedure for larvae in the next experiment.

\section{6. - Attempts to infect eggs, larvae, and pupae with $\mathrm{A}$. apis.}

This experiment was designed to determine whether A. apis would grow on or cause mummification of eggs; small, medium, and large larvae; prepupae; pupae with no eye color; and pupae with eye color. 
The treatment groups are shown in Table 5. Eggs were individually removed from their cells with special forceps (TABER, 1961), rinsed with Roccal, and washed twice with sterile distilled water. Then they were blotted and placed against the side of a sterile vial cap to simulate the position occupied in the cell of the comb. Small and medium larvae were washed from uncapped combs. Large larvae, prepupae, and pupae were washed from combs after uncapping the cells. All larvae were sterilized as described in 5. Pupae were washed with Roccal on the sterile towel on which they were collected; then they were individually held with forceps and rinsed twice with ster-

TABL. 5. - Treatment groups of eggs, larvae, and pupae inoculated with Ascosphaera apis ${ }^{a}$.

\begin{tabular}{|c|c|c|c|}
\hline Treatment & $\begin{array}{l}\text { Site of } \\
\text { inoculation }\end{array}$ & Treatment & $\begin{array}{c}\text { Site of } \\
\text { inoculation }\end{array}$ \\
\hline Eggs & & Large larvae & \\
\hline Live $A$. apis-mated & Body & Dead $A$. apis-unmated & Back \\
\hline Live $A$. apis-unmated & Body & Dead $A$, apis-unmated & Mouthparts \\
\hline Dead A. apis-mated & Body & Prepupae & \\
\hline pis-unmated & Body & Live $A$. apis-mated & Back \\
\hline Small larvae & & Live $A$. apis-mated & $\begin{array}{l}\text { Back } \\
\text { Mouthparts }\end{array}$ \\
\hline Live $A$. apis-mated & Back & Live $A$. apis-unmated & Back \\
\hline Live $A$. apis-mated & Mouthparts & Live $A$. apis-unmated & Mouthparts \\
\hline Live $A$. apis unmated & Back & Dead $A$. apis-mated & Back \\
\hline Live $A$. apis-unmated & Mouthparts & Dead $A$. apis-mated & Mouthparts \\
\hline Dead $A$. apis-mated & Back & Dead $A$. apis-unmated & Back \\
\hline Dead $A$. apis-mated & Mouthparts & Dead $A$. apis-unmated & Mouthparts \\
\hline $\begin{array}{l}\text { Dead } A \text {. apis-unmated } \\
\text { Dead } A \text {. apis-unmated }\end{array}$ & $\begin{array}{l}\text { Back } \\
\text { Mouthparts }\end{array}$ & Pupae-no eye color & \\
\hline Medium larvae & & $\begin{array}{l}\text { Live } A \text {. apis-mated } \\
\text { Live } A \text {. apis-mated }\end{array}$ & $\begin{array}{l}\text { Back } \\
\text { Mouthparts }\end{array}$ \\
\hline Live $A$. apis-mated & Back & Live $A$. apis-unmated & Back \\
\hline Live $A$. apis-mated & Mouthparts & Live $A$. apis-unmated & Mouthparts \\
\hline Live $A$. apis-unmated & Back & Dead $A$. apis-mated & Back \\
\hline Live $A$, apis-unmated & Mouthparts & Dead $A$, apis-mated & Mouthparts \\
\hline Dead $A$. apis-mated & Back & Dead $A$. apis-unmated & Back \\
\hline Dead A. apis-mated & Mouthparts & Dead $A$. apis-unmated & Mouthparts \\
\hline $\begin{array}{l}\text { Dead } A \text {. apis-unmated } \\
\text { Dead } A \text { apis-unmated }\end{array}$ & $\begin{array}{l}\text { Bac } \\
\text { Mol }\end{array}$ & Pupae-eye color & \\
\hline Large larvae & & $\begin{array}{l}\text { Live } A \text {. apis-mated } \\
\text { Live } A \text {. apis-mated }\end{array}$ & $\begin{array}{l}\text { Back } \\
\text { Mouthparts }\end{array}$ \\
\hline Live $A$. apis-mated & Back & Live $A$. apis-unmated & Back \\
\hline Live $A$. apis-mated & Mouth & Live $A$. apis-unmated & Mouthparts \\
\hline Live $A$. apis-unmated & Back & Dead A. apis-mated & Back \\
\hline Live $A$. apis-unmated & Mouthparts & Dead A. apis-mated & Mouthparts \\
\hline Dead $A$. apis-mated & Back & Dead $A$. apis-unmated & Back \\
\hline Dead A. apis-mated & Mouthparts & Dead $A$. apis-unmated & Mouthparts \\
\hline
\end{tabular}


ile distilled water. Each insect was placed in a sterile vial cap and treated as shown in Table 5. Since we noted that the medium and large larvae, prepupae, and pupae required less humidity in the petri dishes than the eggs and small larvae, we added less water to the filter papers in dishes containing these stages. The mummified larvae and prepupae looked more like those from natural hive infections, possibly because of the lower humidity.

All brood was incubated at $25^{\circ} \mathrm{C}$ and observed for 15 days for growth of A. apis and mummification. No growth occurred on any eggs or pupae though a few medium and large larvae and prepupae were contaminated with Aspergillus spp. that were presumably comb contaminants. After incubation for 7 days, several pupae with eye color had developed wings, legs, antennae, and hair.

As shown on Table 6, 26 mummies were formed. However, 12 of these were apparently the result of natural infections of $A$. apis since they were in the control groups inoculated with dead $A$. apis. Of these 12,5 were medium-sized larvae, 5 were large larvae, and 2 were prepupae. Therefore, by experimental inoculation, one mummy was produced in the medium-sized larvae, 8 in the large larvae, and 5 in the prepupae. Thus, more mummies were produced from large larvae though few mummies were produced in any larvae or prepupae. DE JONG and MoRSE (1976) also observed wide variation in infection rates of larvae fed $A$. apis. In the present test, all

TABL. 6. - Mummies and growth of Ascosphaera apis produced by inoculation of eggs, larvae, and pupae with Ascosphaera apis.

\begin{tabular}{|c|c|c|c|c|c|}
\hline \multirow{2}{*}{ Stage } & \multirow{2}{*}{$\begin{array}{c}\text { Site of } \\
\text { inoculation }\end{array}$} & \multirow{2}{*}{ A. apis strain } & \multirow{2}{*}{ Mummies produced } & \multicolumn{2}{|c|}{ Growth of $A$. apis } \\
\hline & & & & Mycelium & Spores \\
\hline $\begin{array}{l}\text { Small larvae } \\
\text { Medium larva } \\
\text { Medium larva } \\
\text { Medium larva } \\
\text { Medium larva } \\
\text { Medium larva } \\
\text { Medium larva } \\
\text { Large larva } \\
\text { Large larva } \\
\text { Large larva } \\
\text { Large larva } \\
\text { Large larva } \\
\text { Large larva } \\
\text { Large larva } \\
\text { Prepupae } \\
\text { Prepupae } \\
\text { Prepupae } \\
\text { Prepupae } \\
\text { Prepupae } \\
\text { Prepupae }\end{array}$ & $\begin{array}{l}\text { Mouthparts } \\
\text { Mouthparts } \\
\text { Back } \\
\text { Mouthparts } \\
\text { Mouthparts } \\
\text { Back } \\
\text { Back } \\
\text { Mouthparts } \\
\text { Mouthparts } \\
\text { Back } \\
\text { Back } \\
\text { Mouthparts } \\
\text { Back } \\
\text { Back } \\
\text { Back } \\
\text { Mouthparts } \\
\text { Back } \\
\text { Mouthparts } \\
\text { Mouthparts } \\
\text { Back }\end{array}$ & $\begin{array}{l}\text { Live-mated } \\
\text { Live-mated } \\
\text { Live-unmated } \\
\text { Dead-mated } \\
\text { Dead-unmated } \\
\text { Dead-mated } \\
\text { Dead-unmated } \\
\text { Live-mated } \\
\text { Live-unmated } \\
\text { Live-mated } \\
\text { Live-unmated } \\
\text { Dead-mated } \\
\text { Dead-mated } \\
\text { Dead-unmated } \\
\text { Live-mated } \\
\text { Live-mated } \\
\text { Live-unmated } \\
\text { Dead-mated } \\
\text { Dead-unmated } \\
\text { Dead-unmated }\end{array}$ & $\begin{array}{l}1 \\
2 \\
1 \\
1 \\
1 \\
1 \\
1 \\
1 \\
5 \\
1 \\
3 \\
1 \\
1 \\
2 \\
2 \\
1 \\
1\end{array}$ & $\begin{array}{l}1 \\
1\end{array}$ & 1 \\
\hline
\end{tabular}


mummies found were white (unmated) to gray (probabably a mixture of mated and unmated strains). Other than the mummies, only 1 small and 1 medium-sized larvae inoculated with live $A$. apis showed any growth of $A$. apis. In these 2 larvae, $A$. apis grew from the mouth, anus, and through the cuticle. None of the other inoculated insects yielded any growth of $A$. apis.

Eggs and pupae of the honey bee are therefore not susceptible to laboratory infection with $A$. apis. Medium and large larvae and prepupae are susceptible with large larvae being the most susceptible. Also, all three of these age groups are susceptible to natural infections. The colony from which these insects were obtained had no visible signs of chalkbrood disease. Perhaps, A. apis resides within bee colonies without causing the overt signs of disease until the proper conditions exist. If chilling is a necessary prerequisite for infection with our strain(s) of $A$. apis as with European strains (BAILEY, 1967), this condition should be met by our procedures for removal of brood from the comb and surface sterilization. However, in Arizona we have noted heavy year-round infections of larvae, even when the average monthly temperatures are $29^{\circ} \mathrm{C}$. The strains of $A$. apis found in Arizona may thus differ from those reported from Europe. We are now investigating this question.

\section{ACKNOWLEDGMENT}

We thank Dinorah Dunham and Leslie CAPIN for their excellent technical assistance with brood in the incubator.

\section{REFERENCES}

Atkins E. L., Todd F. E., Anderson L. D., 1970. - Honey bee field research aided by Todd dead bee hive entrance trap. Calif. Agr., 24, 12-13.

BAILEY L., 1967. - The effect of temperature on the pathogenicity of the fungus, Ascosphaera apis, for larvae of the honey bee, Apis mellifera. In : "Insect Pathology and Microbial Control ", ed. P. A. van der Laan, 162-167, North-Holland, Amsterdam.

BAKER G. M., ToRChio P. F., 1968. - New records of Ascosphaera apis from North America. Mycologia, 60, 189-190.

Barthel B., 1971. - D.r Kalkbrut auf der Spur. Garten u. Kleintierzucht C. Imker, 12-13.

DE JONG D., 1976. - Experimental enhancement of chalk brood infections. Bee World, 57, 114-115.

DE JONG D., Morse R. A. 1976. - Chalk brood: a new disease of honey bees in the U.S. N. Y. Food Life Sci., 9, 12-14.

Gary N. E., Ficken R. W., Stein R. C., 1961. - Honey bee larvae (Apis mellifera, L.) for bird food. Avicult. Mag., 67, 27-32.

Gilliam M., TABER S. III., 1973. - Microorganisms and diseases encountered in continuous bee production. Amer. Bee J., 113, 222-223.

HitchCock J. D., Christensen M., 1972. - Chalk brood disease of honey bees in the United States. Amer. Bee J., 112, 248-249, 254. 
MATUS F., SARBaK I., 1974. - [Occurence of chalkbrood disease in Hungary]. Mayar Allatorvosk Lapia, $29,250-255$.

MAURIzio A., 1934. - Über die Kalkbrut (Pericystis-Mykose) der Bienen. Arch. Bienenkunde, 15, 165 193.

Roussy L., 1962. - Nouvelle contribution à l'étude du Pericystis apis (Mn). Gaz. Apicole, 63, 101-105.

TABER S. III., 1961. - Forceps design for transferring honey bee eggs. J. Econ. Entomol., 54, 247-250.

TABER S. III., 1961. - Forceps design for transferring honey bee eggs. J. Econ. Entomol., 54, 247-250. Bee J., 114, 18-19.

TABer S. III, Sackett R., Mills J., 1975. - A possible control for chalk brood disease. Amer. Bee J., $115,20$.

Thomas G. M., LuCE A., 1972. - An epizootic of chalk brood, Ascosphaera apis (Maassen ex Claussen) Olive and Spiltoir in the honey bee, Apis mellifera L., in California. A mer. Bee J., 112, 88-90.

\title{
RÉSUMÉ
}

\author{
LE COUVAIN PLÂTRÉ CHEZ L'ABEILLE, APIS MELLIFERA L.
}

A de nombreuses reprises on a tenté de contaminer le couvain de colonies de rucher avec Ascosphaera apis, organisme probablement responsable de la maladie du couvain plâtré. Des inocula préparés à partir de cultures artificielles d' $A$. apis ont été comparés avec des suspensions provenant de larves infectées naturellement; les inocula ont été incorporés à des pulvérisations de sirop et/ou à des pains de pollen; on a utilisé des momies qui renfermaient l'agent pathogène à l'état de spores ou à l'état végétatif. Le rapport ouvrières adultes sur couvain a été modifié par la suppression d'abeilles adultes ou de cadres de couvain avant l'application de l'inoculum; des momies broyées ont été appliquées par saupoudrage ou incorporées au pollen.

Les contaminations les plus fortes se sont produites dans des colonies que l'on avait nourries avec du pollen non contaminé pour développer l'élevage de couvain et desquelles on avait ôté un nombre variable d'abeilles adultes avant de vaporiser sur le couvain une suspension de 3 momies noires (renfermant des spores) dans $90 \mathrm{ml}$ d'une solution d'eau à $5 \%$ de sucrose. Quand le traitement fut appliqué 3 fois par jour les $1^{\text {er }}, 3^{e}$ et $5^{\mathrm{e}}$ jours de l'expérience, il provoqua au $6^{\mathrm{e}}$ jour des contaminations élevées ( $10 \%$ du couvain). Pourtant, même ce traitement s'est révélé moins efficace dans d'autres colonies traitées plus tard. Ainsi la variation de la sensibilité peut être un facteur important dans l'expression du couvain plâtré.

A cause de la difficulté d'induire des contaminations dans les colonies de rucher, nous avons imaginé des techniques pour ôter le couvain des rayons, le stériliser en surface, le maintenir en étuve et lui inoculer A. apis. On n'a noté aucune différence dans la survie des larves en étuve, selon qu'elles étaient nourries avec une solution de sucrose à $25 \%$, avec de la gelée royale ou pas nourries du tout. Des suspensions d'A. apis servant d'inocula ont ainsi été préparées en homogénéisant 5 momies noires porteuses de spores ou 5 momies blanc crayeux dans $5 \mathrm{ml}$ d'eau distillée stérile. Les inoculations ont été faites sur les œufs et sur le dos ou les pièces buccales des larves et des nymphes. Les momies furent obtenues à partir de larves d'âge divers et de prénymphes, mais les œufs et les nymphes n'ont pas favorisé la croissance d'A. apis. Il semble qu' $A$. apis puisse envahir les larves par la bouche ou la cuticule. $A$. apis s'est développé, et dans certains cas a sporulé, sur des larves mortes tuées par de la glace séche mais ne les a pas momifiées.

\section{ZUSAMMENFASSUNG}

DIE KALKBRUT DER HONIGBIENE, APIS MELLIFICA L. (EIN ARBEITSBERICHT)

Zahlreiche Versuche wurden unternommen, um in Bienenvölkern die Brut mit $A$ scosphaera apis, dem mutmasslichen Erreger der Kalkbrut, zu infizieren. Infektionsstoffe aus künstlichen Ascosphaera- Kulturen 
wurden auf ihre Wirksamkeit, verglichen mit der von Suspensionen natürlich infizierter Bienenmaden, überprüft. Der Infektionsstoff wurde entweder mit Zuckerwasser aufgesprüht oder in Pollenkuchen verabreicht. Es wurden Mumien benutzt, die den Erreger als Sporenzyste oder als Vegetativform lieferten. Das Verhältnis von erwachsenen Arbeiterinnen zur Brut in den Völkern wurde vor Übertragung des Krankheitserregers durch Entnahme von erwachsenen Bienen oder von Brutwaben verändert. Zerriebene Mumien wurden aufgestäubt oder in Pollen verabreicht.

Die schwersten Infektionen traten in solchen Völkern auf, die zuvor zur Förderung der Brutaufzucht mit Pollen gefüttert worden waren, und von denen unterschiedlich viele erwachsene Bienen entnommen worden waren, bevor die Brut mit einer Suspension von drei schwarzen (mit Sporen behafteten) Mumien in $90 \mathrm{ml}$ einer $5 \%$ igen Zuckerlösung besprüht wurden. Wurde diese Behandlung am 1., 3. und 5 . Versuchstag jeweils dreimal täglich durchgeführt, zeigte sich am 6 . Tag ein schwerer Befall $(10 \%$ der Brut). Diese Behandlung erwies sich jedoch später in anderen Völkern als weniger wirksam. Unterschiede in der Empfänglichkeit dürften ein wichtiger Faktor für das Auftreten der Kalkbrut sein.

Wegen der Schwierigkeiten, die es bereitet, Völker in Bienenständen zu infizieren, entwickelten wir Verfahren zur Entfernung von Brut aus den Waben, zur Oberflächensterilisation der Brut, zur Brutaufzucht im Brutschrank und Infizierung der Brut mit Ascosphaera apis. Im Brutschrank zeigten sich keine Unterschiede in der Überlebensdauer der Maden, einerlei ob sie mit 25 \%iger Zuckerlösung, mit Königinnenfuttersaft oder gar nicht gefüttert wurden. So wurden A. apis- Suspensionen durch Homogenisieren von fünf schwarzen, sporentragenden Mumien oder von fünf weissen, kalkigen Mumien in $5 \mathrm{ml}$ sterilem, destilliertem Wasser hergestellt. Der Impfstoff wurde auf Eier und Rücken und Mundpartie von Maden und Puppen aufgetragen. Aus verschieden alten Maden und aus Streckmaden entstanden Mumien; Eier und Puppen förderten das Wachstum von Ascosphaera apis jedoch nicht. Offensichtlich kann $A$. apis durch den Mund und durch die Cuticula in die Made eindringen. Gelegentlich sporulierte Ascosphaera apis auf mit Trockeneis abgetöteten Maden, mumifizierte sie aber nicht. 